\title{
Population dynamics of five sigmodontine rodents of northwestern Patagonia
}

\author{
Nadia GUTHMANN, Mariana LOZADA, \\ Jorge A. MONJEAU and Karin M. HEINEMANN
}

Guthmann N., Lozada M., Monjeau J. A. and Heinemann K. M. 1997. Population dynamics of five sigmodontine rodents of northwestern Patagonia. Acta Theriologica 42: $143-152$.

Population dynamics of five rodent species were studied, from March 1991 to August 1994, in an area located in the ecotonal steppe of northwestern Patagonia, Argentina (at about $40^{\circ} \mathrm{S}$ ). Seasonal and annual fluctuations in population numbers were found in all sigmodontine species. The reproductive period, sex ratio and longevity of the five species were also studied. Abrothrix xanthorhinus (Waterhouse, 1837), a habitat generalist, was the most abundant species. Eligmodontia morgani (Allen, 1901), Abrothrix longipilis (Waterhouse, 1837), Reithrodon auritus (Fischer, 1814) and Oligoryzomys longicaudatus (Bennett, 1832) were subdominant. The present study is a first description of the population dynamics in this rodent community, whose ecological characteristics gather importance considering that some of these species are Hantavirus reservoirs.

Universidad Nacional del Comahue, Departamento de Ecología, Unidad Postal Universidad del Comahue, Bariloche 8400, Río Negro, Argentina

Key words: rodents, population dynamics, Patagonia, Argentina

\section{Introduction}

Communities are dynamic entities; consequently, an understanding of community structure is possible only within the appropriate framework of temporal and spatial variation (Wiens 1986, Morris 1990). Among rodent species, population fluctuations may vary on the order of seasons or years (Lidicker 1988, Anderson et al. 1992, Krebs 1992). Therefore, long term studies are important to understand rodent community structure and species coexistence (M'Closkey 1972, Kaufman et al. 1995).

In this study we examined a rodent community over a period of 42 months in northwestern Patagonia. The study area is located in a transition zone, of a few kilometres wide, between the western Andean forest and the eastern semiarid Patagonian steppe. Each biome, on either side of this ecotonal strip, contains characteristic small mammal faunas which have been studied by many authors (eg Murúa and González 1981, 1982, 1986, González et al. 1982, 1989, Meserve et al. 1982, 1988, 1991, Glanz 1984, Meserve and Le Boulengé 1987, Murúa et al. 
1987, Pearson et al. 1987, Pearson 1988, 1992, Patterson et al. 1989). The ecstonal fauna has no endemic species, rather it consists of assemblages of forest and steppe rodents (eg Pearson and Pearson 1982, Johnson et al. 1990, Kelt 1994, 1996). The steppe species found in this study were Abrothrix xanthorhinus (Waterhouse, 1837), Eligmodontia morgani (Allen, 1901) and Reithrodon auritus (Fischer, 1814). The first is an omnivorous small mouse $(82 \mathrm{~mm}$ of head-body length and $52 \mathrm{~mm}$ of tail length, $17 \mathrm{~g}$ ) that inhabits the semiarid steppe and bunchgrass in aorthwestern Patagonia (Pearson 1995). The second is a granivorous small mouse ( 82 and $82 \mathrm{~mm}, 20 \mathrm{~g}$ ) of sandy soils and open vegetation, and the third is an herbivorous large mouse (130 and $85 \mathrm{~mm}, 80 \mathrm{~g}$ ) of open grassy areas (Pearson 1988, 1995, Pearson et al. 1987). The forest species were Abrothrix longipilis (Waterhouse, 1837) a medium sized, omnivorous mouse (105 and $80 \mathrm{~mm}, 38 \mathrm{~g}$ ) widely dispersed from dense forests to marshes and bushy steppe, and Oligoryzomys longicaudatus (Bennett, 1832) a granivorous mouse (95 and $120 \mathrm{~mm}, 37 \mathrm{~g}$ ) abundant in brush areas and forest edges (Meserve et al. 1982, Pearson 1995, Patterson et al. 1989).

Previous studies performed in this transition habitat focused on the distribution of small mammals and community characteristics such as species richness and diversity, demography, reproduction, trophic structure, and the relative size of populations (Pearson and Pearson 1982, Pearson 1995, Johnson et al. 1990, Kelt 1994, 1996). However, long term studies of these rodent communities have not been previously undertaken. In addition, information about ecological aspects of the studied species has become relevant since the detection, in this region, of Hantavirus Pulmonary Syndrome transmitted by sigmodontine rodents.

This work examines the population dynamics of the five most representative species of a rodent community in a Patagonian transition zone. Changes in relative abundance of rodent populations over time, seasonality of reproduction, sex ratio and longevity are analysed.

\section{Material and methods}

The study site was an ecotonal steppe located in a flat area, $8 \mathrm{~km}$ east of Bariloche Argentina $\left(41^{\circ} \mathrm{S}, 71^{\circ} \mathrm{W}\right)$. Its vegetation consists of patches of low grass (Stipa speciosa), xerophylcus cushion plants (Acaena splendens) and bushes characteristically either of the steppe (Senecio bracteolatus, Baccharis linearis, Discaria articulata) or of the Andean forest (Schinus patagonicus, Berberis spp.). The European rose bush, Rosa rubiginosa is also abundant. The region receives strong westerly winds and has a mean annual temperature of $8^{\circ} \mathrm{C}$, a mean maximum temperature of $14.1 \mathrm{C}$, a mean minimum temperature of $2.4^{\circ} \mathrm{C}$. The mean annual precipitation is $800 \mathrm{~mm}$ and it is concentrated in autumn and winter (March to September) (Bariloche Airport Meteorological Service). The combined increase in temperature and decrease in rainfall during spring and summer (October to February) cause a moderate hydric stress (Barros and Mattio 1977).

Rodents were sampled monthly from March 1991 to November 1994 on a $10 \times 10$ Sherman trap grid with a $10 \mathrm{~m}$ inter-station distance. In each trapping session, traps were set on 4 consecutive days and were baited with rolled oats. The caught animals were toe-clipped for identification. Species were determined following Monjeau et al. (1994), and data such as sex, reproductive condition and body 
measurements (weight, total length and tail length) were recorded. The reproductive condition was assessed by taking into account the scrotal position of testes in males, and in females by detecting perforated vaginas, pregnancy by palpation, increased nipple size, and milk production.

The abundance of each species was estimated by the direst enumeration method using a calendar of captures, and was expressed as the minimum number known alive (MNKA) (Krebs 1966). Individuals that had not been captured for more than 3 montths were considered absent from the grid in that period. Abundance fluctuations were compared between years for each species and for the community by means of a Kolmogorov-Smirnov two sample test (Conover 1980). The period considered for this test ran from March to August of each year, in order to compare the four years.

Abundance coefficients of variation (CV) of each species and of the total community were estimated for the 42 month sampling period. The differences between each species' CV and the total community CV were tested following Zar (1984). Non-parametric correlations between species abundances were calculated by means of the Spearman coefficient. As populations fluctuate seasonally, only the period of February through June was considered, which is when abund ance peaks occurred for all species.

Sex ratio, expressed as number of females over the total number of individuals, was estimated for the total sampling period. Deviations from 0.50 were tested using a $\chi^{2}$-test. Individuals of lower body weight than the lowest weight of reproductive individuals found in all the study period were considered juveniles. The monthly proportion of reproductive animals for each sex was calculated as a ratio of reproductive individuals referred to the number of adults. Adult individuals captured only in a single trapping session were considered transients. A monthly residence indicator was expressed as the proportion of individuals that were recaptured one or more months later. The mean length of residence on the grid was also estimated, excluding transients.

Individuals were classified into cohorts according to their birth periods. As the capture-recapture method does not allow estimates of individual relative age by measuring tooth wear, other sources of evidence were used to determine age (Meserve and Le Boulengé 1987). Body weight over time of individuals captured as juveniles was used to estimate the age of other adult individuals. In addition, data on reproductive condition, individual residence period, and season when caught supported the cohort estimation based on body weight. Transients were excluded from this estimation. The longevity of each species was inferred by means of the longest residence duration and the estimated age from the cohort study.

\section{Results}

The total number of captures was 3545 in a trapping effort of 16800 trap-nights. Individuals of five species of murid rodents were captured: 360 Abrothrix xanthorhinus, 130 A. longipilis, 196 Eligmodontia morgani, 65 Reithrodon auritus, 106 Oligoryzomys longicaudatus.

\section{Abundance fluctuations}

Seasonal fluctuations occurred in all species. Total community abundance peaks occurred from February through May (summer-autumn). These maximum values varied from 70 to $95 \mathrm{MNKA}$ (Fig. 1). On the other hand, the minimum community abundance values occurred from July through December (winter-spring). The total abundance fluctuation did not differ significantly from year to year.

The definite moment at which each population peaked annually differed between species. Population peaks of A. xanthorhinus and A. longipilis occurred at the end of summer-beginning of fall (February-March), but A. longipilis tended to peak earlier (usually in February). $R$. auritus and $E$. morgani were most 
abundant at the end of fall (April-May). E. morgani population maxima were generally later than those of $R$. auritus. Abundance peaks in $O$. longicaudatus occurred both in spring (October) and in autumn (April-May) (Fig. 1).

A. xanthorhinus was the most abundant species during the study. Abundance peaks consisted of 60 MNKA in 1991 and 1993, and approximately 35 MNKA in 1992 and 1994. Abundance minima occurred in spring (September-December) with about $20 \mathrm{MNKA}$ in 1992 and 1993, and less than $10 \mathrm{MNKA}$ in 1991. The 1993 abundance curve differed significantly from that of 1992 and $1994(p<0.05)$.

E. morgani presented abundance peaks similar to A. xanthorhinus in the two first years. However, their numbers decreased about 50\% per year, from $60 \mathrm{MNKA}$ in 1991 to less than 10 MNKA in 1994 (Fig. 1). The 1991 abundance fluctuation curve differed significantly from the 1993 and 1994 curves. Moreover, the 1992 abundance curve differed significantly from the 1994 one $(p<0.05)$. Population minima of $E$. morgani were always much lower than those of $A$. xanthorhinus.

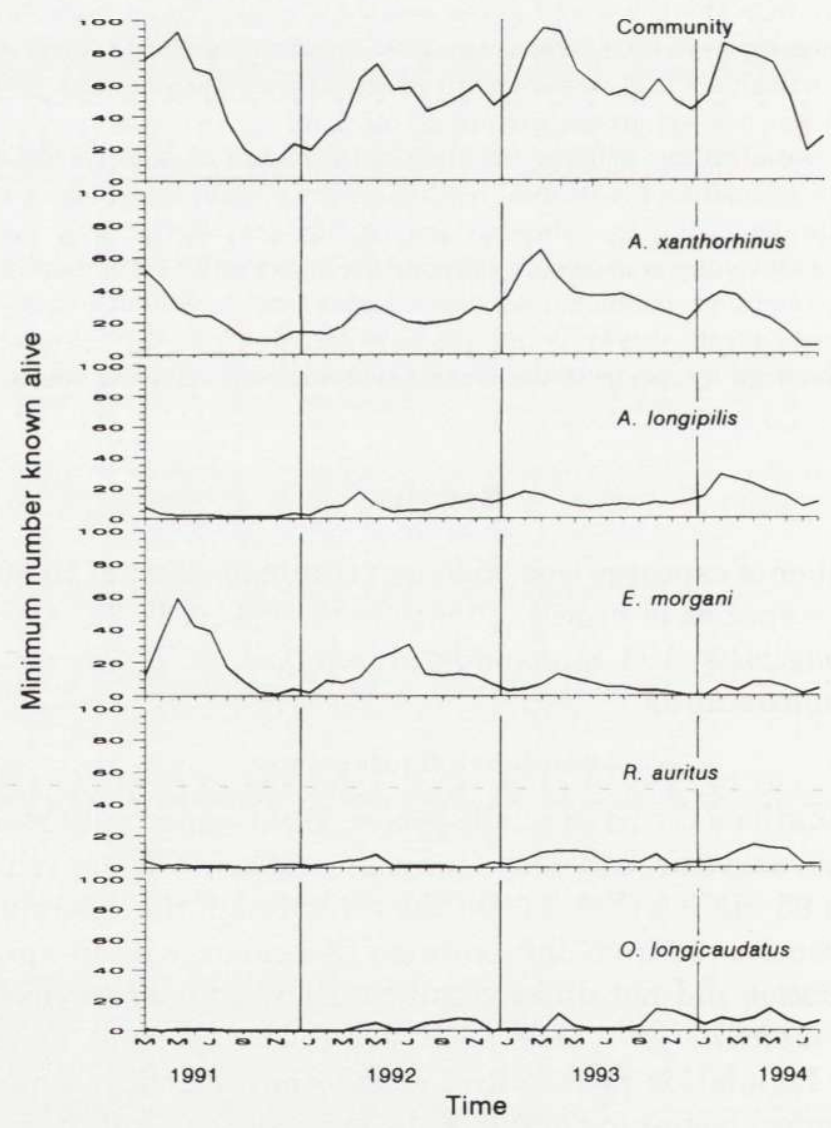

Fig. 1. Abundance fluctuations, expressed as minimum number known alive, of the total community and of each of the five species. March 1991 through August 1994. 
A. longipilis, $R$. auritus and $O$. longicaudatus population numbers were scarce at the beginning of the study but increased during the years. A. longipilis was the most abundant of them (30 MNKA in 1994) (Fig. 1). Its 1991 abundance curve differed significantly from the following years $(p<0.05)$. R. auritus and $O$. longicaudatus reached abundance peaks of about 10 MNKA in 1993 and 15 MNKA in 1994. Abundance curves of $R$. auritus differed significantly between 1991 and 1993, while $O$. longicaudatus showed significant differences between 1991 and 1994, and between 1992 and $1994(p<0.05)$. The populations of $R$. auritus and $O$. longicaudatus presented very low minimum abundances.

The abundance coefficients of variation of A. xanthorhinus (49\%) and of the total community (40\%) were both significantly lower than those of A. longipilis (70\%), E. morgani $(110 \%)$, R. auritus $(94 \%)$ and $O$. longicaudatus $(112 \%)(p<0.05)$. Spearman rank correlation coefficients among population abundances of A. longipilis, $R$. auritus and $O$. longicaudatus were significant and positive $\left(r_{\mathrm{S}}=0.70\right.$ between $A$. longipilis and $R$. auritus, $r_{\mathrm{S}}=0.60$ between $A$. longipilis and $O$. longicaudatus, and $r_{\mathrm{S}}=0.71$ between $R$. auritus and $O$. longicaudatus, $p<0.01$ ). The correlations between $E$. morgani and the above mentioned species were negative $\left(r_{\mathrm{S}}=-0.79\right.$ with $A$. longipilis, $p<0.001 ; r_{\mathrm{S}}=-0.59$ with $R$. auritus, $p<0.01$; and the negative correlation with $O$. longicaudatus was not significant). Insignificant correlations were found between A. xanthorhinus and the other species.

\section{Abrothrix xanthorhinus}

Two cohorts were discriminated in A. xanthorhinus population: (a) individuals born from October to January which reproduce in the same reproductive season, (b) individuals born from February on, which reproduce in the following reproductive season (Fig. 2). From April or May until winter neither cohort differed in body weight. Adults captured in spring (September to December) were overwintering individuals born during the previous summer. These individuals seldom survived until their second summer. The mean body weight tended to decrease during winter and increase at the beginning of spring (Fig. 2).

A. xanthorhinus population did not present significant differences in sex ratios (proportion of males $=0.54, n=350$ ). The reproductive period was relatively long (August to April) (Fig. 2). Juveniles (individuals lighter than $12 \mathrm{~g}$ ) began to be captured as of October-November, two months after the detection of the first adults in reproductive condition (Fig. 2). The highest percentage of reproductive individuals was recorded during spring (higher than 60\%) and the highest percentage of juveniles was observed in summer.

The mean residence time of individuals was 4.6 months. The proportion of transients captured during the complete study was $47 \%$. The monthly residence was quite high (70\%). The longest individual follow-ups were 12 month. These individuals were captured for the first time when they were one or two months old, suggesting a longevity of about 14 months. 


\section{Abrothrix longipilis}

The breeding period was relatively short (September to March) and no individuals were found to reproduce during their birth year. Therefore, only one annual cohort was recognised (Fig. 2). Individuals could survive for up to two reproductive seasons later, and therefore individuals of three different annual cohorts were found to coexist. Juveniles (less than $19 \mathrm{~g}$ ) were captured during three months only, mostly during February (Fig. 2). The mean body weight tended to decrease during winter and increase during spring, as described in A. xanthorhinus (Fig. 2).

Sex ratio of this species was generally biased towards males (proportion of males $=0.70, n=130, p<0.05)$. The mean residence time of individuals was of 5.45 months, and was the highest compared with the other four species. The monthly residence rates were generally high (70\%) but decreased during spring and the beginning of summer when overwintering individuals tended to disappear and the proportion of transients tended to increase. The proportion of transient

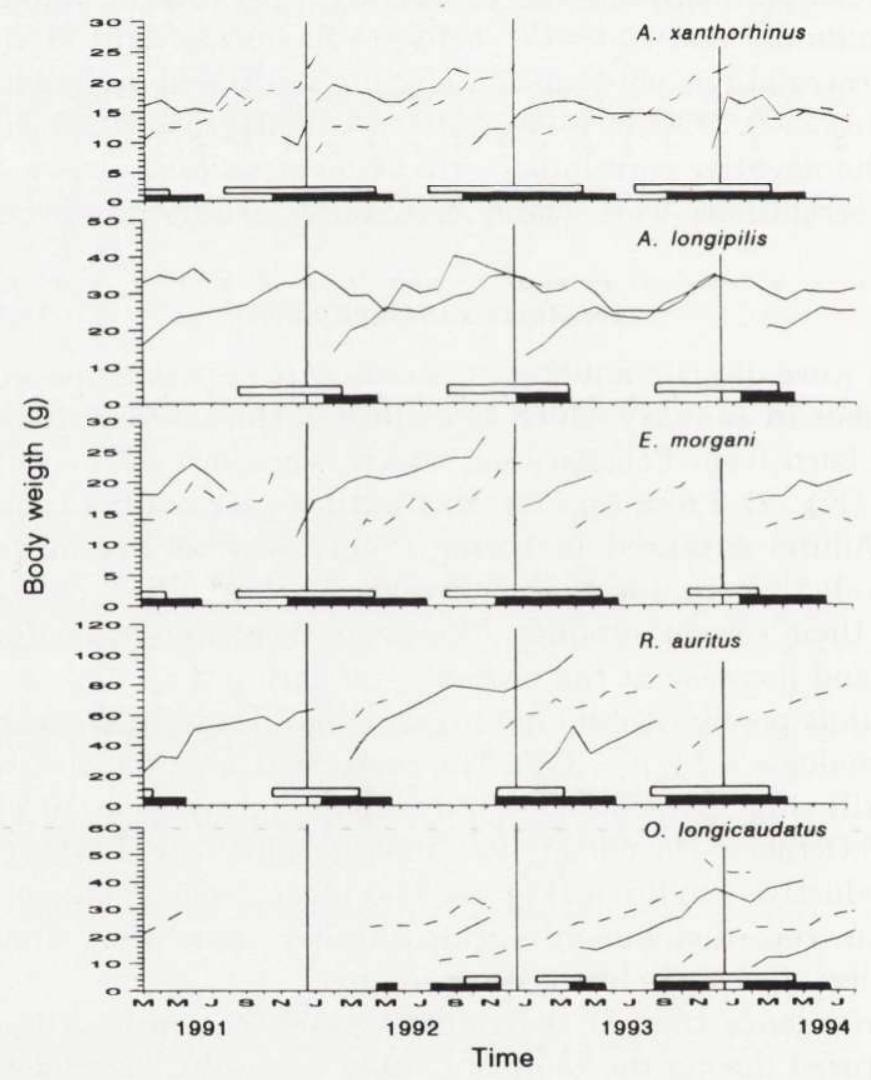

Fig. 2. Cohorts. Fluctuations of body weight means of the distinct cohorts of each species from March 1991 through August 1994. The solid lines represent the spring cohorts and the dashed lines correspond to the summer cohorts. The white bars at the foot of each graph indicate breeding activity, and the black bars indicate the period when juveniles were captured. 
individuals during the complete study was $47 \%$, similar to that of A. xanthorhinus. Some overwintering adults were recaptured for 14 months. These data together with the cohort study (Fig. 2) suggest a longevity of two years.

\section{Eligmodontia morgani}

Two cohorts were defined, as in A. xanthorhinus (Fig. 2). The mean body weight of the summer cohort tended to decrease during winter and increase at the beginning of spring (Fig. 2). The breeding period was long (September to May) and the highest number of reproductive individuals was recorded during fall (March to May) (Figs 1 and 2). Juveniles (less than $17 \mathrm{~g}$ ) were captured from December to July, but they were scarce during summer. The sex ratio was male biased (proportion of males $=0.64, n=180, p<0.05$ ).

The mean residence was 4.11 months. The monthly residence rates were lower than those of $A$. xanthorhinus and A. longipilis. A marked population discontinuity was observed in the spring-summer period. This corresponds with a high proportion of individuals captured for the last time during spring, and a predominance of transients at the end of spring and the beginning of summer. The proportion of transients over the whole study was $52 \%$. The longest residence time (11 months) and the study of cohorts suggest a longevity of 1 year.

\section{Reithrodon auritus}

Reproductive individuals were captured from September to March (Fig. 2). Juveniles (less than $50 \mathrm{~g}$ ) were recorded in spring (October to December) and in higher number and proportion during summer-fall (December to April) (Fig. 2). Two cohorts were distinguished: (a) individuals captured as juveniles in summer that could be recaptured until the following autumn, (b) individuals captured as juveniles in spring that could survive until the following spring (Fig. 2).

The sex ratio did not differ from 0.50 (proportion of males $=0.56$ ). The mean permanence of individuals was 3.7 months. The monthly residence rate was particularly low during spring. The proportion of transients captured during the whole study was $48 \%$. The longest follow-ups of individuals were 8 months, but the study of cohorts suggests a longevity of 15 months (Fig. 2).

\section{Oligoryzomys longicaudatus}

Reproductive individuals were captured from September to April (Fig. 2). Two cohorts were differentiated: (a) juveniles (less than $17 \mathrm{~g}$ ) captured in early spring that could be recaptured until the following summer, (b) juveniles recruited in late summer and fall that could be recaptured until the following autumn (Fig. 2). There were no significant biases in sex ratio (proportion of males $=0.50$ ).

Residence rates were low and the monthly transient proportions were high. The proportion of transients captured throughout the whole study was very high ( $80 \%)$, and the mean residence low (3.3 months). The longest individual follow-ups were 9 months. However, the study of cohorts suggests a longevity of 18 months (Fig. 2). 


\section{Discussion}

Most sigmodontine populations of the studied rodent community showed interannual changes in abundance. The relatively high variation coefficients found throughout the total survey period were related to a marked decrease in the population of E. morgani and to the gradual increases in abundance of A. longipilis, $O$. longicaudatus and $R$. auritus. A. xanthorhinus presented the highest abundance, with minor variation, over the years. In spite of the noticeable interannual variations in abundance of most of the species, the total population number of the whole community did not differ significantly between years. The complementarity of certain population changes (negative Spearman rank correlations) contributed to the stabilisation of the sigmodontine assemblage fluctuations.

Moreover, all five populations studied presented seasonal fluctuations although each species' peak occurred at a different time and with a dissimilar magnitude. A. xanthorhinus and A. longipilis showed moderate seasonal fluctuations, high survival and low emigration rates (suggested by the high monthly residence). A. xanthorhinus had a long and continuous reproductive period while A. longipilis longevity was relatively high. Previous studies highlight the relative population stability of the latter species (Meserve et al. 1982, Pearson 1983, Meserve and Le Boulengé 1987). On the other hand, $R$. auritus, E. morgani and O. longicaudatus presented abrupt seasonal decreases in abundance as described in other studies for the latter two species (Meserve 1981, Meserve and Le Boulengé 1987, Pearson et al. 1987). For $O$. longicaudatus, the high frequency of transients and first-time captures of adults of this relatively long-lived species, suggest an important role of migration in its population dynamics. The observed spring population turnover of $E$. morgani agrees with the short life span of this species.

The cohort study shows a body weight decrease during winter (June through August) and an increase in spring (October through December) as has been observed in other small mammals of temperate environments (eg Iverson and Turner 1974, Wirminghaus and Perrin 1993). Body weight decrease could be related to the usual harsh winter conditions. Some authors have found a correlation between body weight increase in spring and reproduction, body fat accumulation and diet quality (eg Evans 1973, Wirminghaus and Perrin 1993). The sexual maturation delay in summer cohorts as was observed during this study, has also been described for other rodent species (eg González and Murúa 1985, Zuleta et al. 1988). A. longipilis individuals became sexually mature a year after they were born as described by Pearson (1992).

Due to the fact that Hantavirus Pulmonary Syndrome (HPS) is seriously affecting this region and that sigmodontine species are its vector, studies on rodent population dynamics may contribute to the clarification of the relationship between the ecological characteristics of the reservoirs and the occurrence of the disease. For instance, it was recently found that $O$. longicaudatus is one of the Hantavirus reservoirs, and the higher frequency of HPS cases is concordant with the increase 
in abundance of this particular rodent (ie spring and autumn) (N. Guthmann, pers. obs., Argentine National Public Health).

The current study is a first approach towards a long term analysis of ecological characteristics of five sigmodontine rodents in the northwest Patagonian steppe. It describes different population dynamics that could reflect distinct life strategies of five coexisting species in the transition zone. This population pattern approach might enable future studies which develop and test hypotheses about the processes driving these fluctuations.

Acknowledgements: We wish to thank Dr O. Pearson and Dr R. Murúa for their valuable advice and for reading early versions of this manuscript. We also appreciate the helpful comments and suggestions of anonymous reviewers. The translation of this manuscript was possible thanks to B. Drausal, D. Lozada, and A. Schwartz. This research was supported by Consejo Nacional de Investigaciones Científicas y Técnicas de la República Argentina (CONICET) and to the University of Comahue.

\section{References}

Anderson H. M., Hutson V. and Law R. 1992. On the conditions for permanence of species in ecological communities. American Naturalist 139: 663-668.

Barros V. R. and Mattio H. 1977. Tendencias y fluctuaciones en la precipitación de la región patagónica. Meteorológica 8: 237-248.

Conover W. J. 1980. Practical nonparametric statistics. 2 ed. Texas Tech University, Lubbock: 1-493.

Evans D. M. 1973. Seasonal variation in the body composition and nutrition in the vole Microtus agrestis. Journal of Animal Ecology 42: 1-18.

Glanz W. E. 1984. Ecological relationships of two species of Akodon in central Chile. Journal of Mammalogy 65: 433-441.

González L. and Murúa R. 1985. Características del período reproductivo de tres especies de roedores cricétidos del bosque higrófilo templado. Anales del Museo de Historia Natural de Valparaíso (Chile) 16: 87-99.

González L., Murúa R. and Feito R. 1982. Densidad poblacional y patrones de actividad espacial de Akodon olivaceus (Rodentia, Cricetidae) en hábitats diferentes. [In: Actas del VIII Congreso Latinoamericano de Zoología. P. Salinas, ed]. Mérida, Venezuela: 935-947.

González L., Murúa R. and Jofré C. 1989. The effect of seed availability on population density of Oryzomys in southern Chile. Journal of Mammalogy 70: 401-403.

Iverson S. L. and Turner B. N. 1974. Winter weight dynamics in Microtus pennsylvanicus. Ecology 55: 1030-1041.

Johnson W. E., Franklin W. L. and Iriarte J. A. 1990. The mammalian fauna of the northern Chilean Patagonia: a biogeographical dilemma. Mammalia 54: 457-469.

Kaufman D. W., Kaufman A. and Finck E. J. 1995. Temporal variation in abundance of Peromyscus leucopus in wooded habitats of eastern Kansas. American Midland Naturalist 133: 7-17.

Kelt D. A. 1994. The natural history of small mammals from Aisén Region, southern Chile. Revista Chilena de Historia Natural 67: 183-207.

Kelt D. A. 1996. Ecology of small mammals across a strong environmental gradient in southern South America. Journal of Mammalogy 77: 205-219.

Krebs C. J. 1966. Demographic changes in fluctuating populations of Microtus californicus. Ecological Monographs 36: 239-273.

Krebs C. J. 1992. The role of dispersal in cyclic rodent populations. [In: Animal dispersal. Small mammals as a model, N. C. Stenseth and W. Z. Lidicker Jr, eds]. Chapman \& Hall, London: 160-173.

Lidicker W. Z., Jr 1988. Solving the enigma of microtine "cycles". Journal of Mammalogy 69: 225-235.

M'Closkey R. T. 1972. Temporal changes in population and species diversity in a California rodent community. Journal of Mammalogy 53: 657-676. 
Meserve P. L. 1981. Resource partitioning in a Chilean semiarid small mammal community. Journal of Animal Ecology 50: 745-757.

Meserve P. L., Lang B. K., Murúa R., Muoz-Pedreros A. and González L. 1991. Terrestrial small mammals characteristics in a primary growth Chilean temperate rainforest. Revista Chilena de Historia Natural 64: 157-169.

Meserve P. L., Lang B. K. and Patterson B. D. 1988. Trophic relationships of small mammals in a Chilean temperate rainforest. Journal of Mammalogy 69: 721-730.

Meserve P. L. and Le Boulengé E. 1987. Population dynamics and ecology of small mammals in the northern Chilean semiarid region. [In: Studies in neotropical mammalogy: essays in honor of Philip Hershkovitz. B. D. Patterson and R. M. Timm, eds]. Fieldiana: Zoology, New Series, 39: 413-431.

Meserve P. L., Murúa R., Lopetegui O. N. and Rau J. R. 1982. Observations on the small mammal fauna of a primary temperate rain forest in southern Chile. Journal of Mammalogy 63: 315-317.

Monjeau J. A., Bonino N. and Saba S. L. 1994. Annotated checklist of the living land mammals in Patagonia, Argentina. Mastozoología Neotropical 1: 143-156.

Morris D. W. 1990. Temporal variation, habitat selection and community structure. Oikos 59: 303-312.

Murúa R. and González L. A. 1981. Estudios de preferencias y hábitos alimentarios en dos especies de roedores cricétidos. Medio Ambiente, Valdivia, Chile 5: 115-124.

Murúa R. and González L. A. 1982. Microhabitat selection in two Chilean cricetid rodents. Oecologia 52: $12-15$.

Murúa R. and González L. A. 1986. Regulation of numbers in two Neotropical rodent species in southern Chile. Revista Chilena de Historia Natural 59: 193-200.

Murúa R., Meserve P. L., González L. A. and Jofré C. 1987. The small mammal community of a Chilean temperate rainforest: lack of evidence of competition between dominant species. Journal of Mammalogy 68: 729-738.

Patterson B. D., Meserve P. L. and Lang B. K. 1989. Distribution and abundance of small mammals along an elevational transect in temperate rain forests of Chile. Journal of Mammalogy 70: 67-78.

Pearson O. P. 1983. Characteristics of a mammalian fauna from forests in Patagonia, southern Argentina. Journal of Mammalogy 64: 476-492.

Pearson O. P. 1988. Biology and feeding dynamics of a South American herbivorous rodent, Reithrodon. Studies on Neotropical Fauna and Environment 23: 29-39.

Pearson O. P. 1992. Reproduction in a South American mouse, Abrothrix longipilis. The Anatomical Record 234: 73-88.

Pearson O. P. 1995. Annotated keys for identifying small mammals living in or near Nahuel Huapi National Park or Lanín National Park, southern Argentina. Mastozoología Neotropical 2: $99-148$.

Pearson O. P., Martin S. and Bellati J. 1987. Demography and reproduction of the silky desert mouse (Eligmodontia morgani) in Argentina. [In: Studies in neotropical mammalogy: essays in honor of Philip Hershkovitz. B. D. Patterson and R. M. Timm, eds.]. Fieldiana: Zoology, New Series, 39: 433-446.

Pearson O. P. and Pearson A. K. 1982. Ecology and biogeography of the southern rainforests of Argentina. [In: Mammalian biology in South America. M. A. Mares and H. H. Genoways, eds.]. Pymatuning Symposium of Ecology 6: 129-142.

Wiens J. A. 1986. Spatial scale and temporal variation in studies of shrubsteppe birds. [In: Community ecology. J. Diamond and T. J. Case, eds]. Harper and Row, New York: 154-72.

Wirminghaus J. O. and Perrin M. R. 1993. Seasonal changes in density, demography and body composition of small mammals in a southern temperate forest. Journal of Zoology 229: 303-318.

Zar J. H. 1984. Biostatistical Analysis. Prentice Hall, Englewood Cliffs, New Jersey: 1-718.

Zuleta G. A., Kravetz F. O., Busch M. and Percich R. E. 1988. Dinámica poblacional del ratón del pastizal pampeano (Akodon azarae) en ecosistemas agrarios de Argentina. Revista Chilena de Historia Natural 61: 231-244.

Received 27 June 1996, accepted 1 March 1997. 